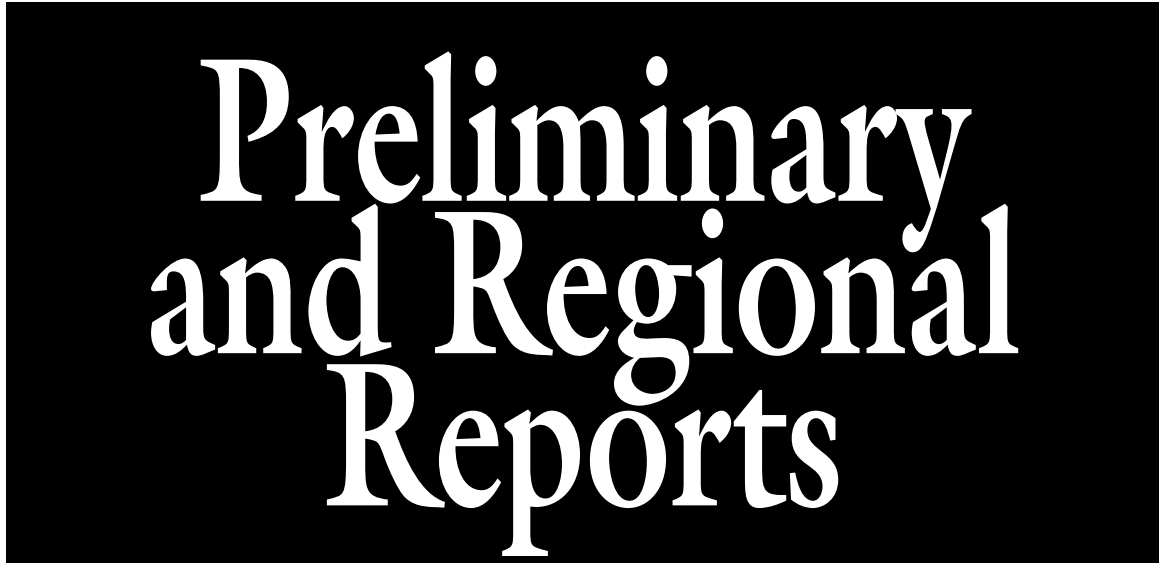

\section{Simulated Single Drift Events of 2,4-D and Dicamba on Pecan Trees}

\author{
M. Lenny Wells ${ }^{1,3}$, Eric P. Prostko ${ }^{2}$, and O. Wendell Carter ${ }^{2}$
}

AdDitional Index words. Carya illinoinensis, herbicide drift, herbicide damage

SuMmary. A large number of agronomic and horticultural crops are susceptible to injury and yield loss from drift-level exposures to synthetic auxin herbicides. A new generation of genetically modified crops including cotton (Gossypium birsutum), field corn (Zea mays), soybean (Glycine max), and canola (Brassica napus) with resistance to dicamba and $2,4-\mathrm{D}$ herbicides has been developed to address the problem of glyphosate-resistant weeds. In the few years since their commercial introduction, these technologies have been rapidly adopted. The objective of this study was to determine the potential effects of simulated, single drift events of 2,4-D and dicamba on pecan (Carya illinoinensis) trees. 2,4-D amine [3.8 lb/gal acid equivalent (a.e.)] or dicamba-Diglycolamine salt $(4.0 \mathrm{lb} / \mathrm{gal}$ a.e. $)$ were applied in $1.0 \%, 0.1 \%$, and $0.01 \%$ by volume spray solutions to pecan trees in June 2013 . In 2016 and $2017,2,4-\mathrm{D}$ choline $(3.8 \mathrm{lb} / \mathrm{gal}$ a.e. $)$ or dicamba-N,N-Bis-(3-aminopropyl) methylamine $(5.0 \mathrm{lb} / \mathrm{gal}$ a.e. $)$ were applied in $1.0 \%, 0.1 \%$, and $0.01 \%$ by volume spray solutions to pecan trees in May. These results suggest that serious injury can occur to pecan trees receiving a drift application of $1.0 \%$ by volume dicamba or 2,4-D. This injury includes deformed foliage, dead foliage, dead limbs, and/or branches, and arrested nut development. There were no major differences in the response of pecan to either dicamba or 2,4-D at similar rates in this study. Pecan damage resulting from off-target movement of $2,4-\mathrm{D}$ and dicamba at rates $\geq 1 \%$ by volume has the potential to cause significant injury. Yield was not negatively affected by any of the treatments, suggesting that pecan trees can compensate for the observed injury to some extent. The effect of treatments on percent kernel was variable.

$\mathrm{T}$ he commercialization of genetically modified crops resistant to the herbicide glyphosate

Received for publication 7 Jan. 2019. Accepted for publication 20 Feb. 2019.

Published online 2 April 2019.

${ }^{1}$ University of Georgia, Department of Horticulture, 4604 Research Way, Tifton, GA 31793

${ }^{2}$ University of Georgia, Department of Crop \& Soil Sciences, 4604 Research Way, Tifton, GA 31793

${ }^{3}$ Corresponding author. E-mail: lwells@uga.edu.

This is an open access article distributed under the CC BY-NC-ND license (https://creativecommons.org/ licenses/by-nc-nd/4.0/).

https://doi.org/10.21273/HORTTECH04265-19 revolutionized agricultural weed management in the mid-1990s (Mortensen et al., 2012). By 2008, glyphosateresistant crops were grown in $63 \%$,
$68 \%$, and $92 \%$ of U.S. corn, cotton, and soybean acreage, respectively (Duke and Powles, 2009). The increased use of glyphosate in the agricultural landscape has led to the development of glyphosate resistance in 43 weed species (Heap, 2018).

A new generation of genetically modified crops, including cotton, field corn, soybean, and canola with resistance to dicamba and 2,4-D herbicides has been developed to address the problem of glyphosate-resistant weeds (Behrens et al., 2007; Wright et al., 2010). In the few years since their commercial introduction, these technologies have been rapidly adopted. In $2018,81 \%$ of the cotton cultivars planted in Georgia were tolerant of dicamba (U.S. Department of Agriculture, 2018).

Dicamba and 2,4-D are both synthetic auxin herbicides, which have been widely used for broadleaf weed control in corn, cereals, and pastures for more than 40 years (Monaco et al., 2002). These herbicides mimic the physiological effects of auxin-type plant growth regulators and can cause abnormal growth and eventually mortality in a wide variety of broadleaf plant species. In addition, some older formulations of dicamba and 2,4-D have high volatility (Grover et al., 1972), potentially leading to off-target damage of susceptible plants under certain environmental conditions.

Off-target movement can potentially occur with any herbicide, resulting in negative impacts on nontarget vegetation from wind-dispersed particles (drift) and/or as vapors evaporating from another application surface (volatility). Previous experience with injury to susceptible crops has indicated synthetic auxin herbicides may be especially prone to off-target problems due to volatility and efficacy at low rates (Behrens and Lueschen, 1979; Sciumbato et al., 2004). Herbicide application under appropriate weather conditions with the recommended application equipment

\begin{tabular}{llll}
\hline $\begin{array}{l}\text { Units } \\
\begin{array}{l}\text { To convert U.S. to SI, } \\
\text { multiply by }\end{array}\end{array}$ & U.S. unit & SI unit & $\begin{array}{l}\text { To convert SI to U.S., } \\
\text { multiply by }\end{array}$ \\
\hline 29.5735 & $\mathrm{fl} \mathrm{oz}$ & $\mathrm{mL}$ & 0.0338 \\
0.3048 & $\mathrm{ft}$ & $\mathrm{m}$ & 3.2808 \\
9.3540 & gal $/ \mathrm{acre}$ & $\mathrm{L} \cdot \mathrm{ha}^{-1}$ & 0.1069 \\
2.54 & inch $(\mathrm{es})$ & $\mathrm{cm}$ & 0.3937 \\
0.4536 & $\mathrm{lb}$ & $\mathrm{kg}$ & 2.2046 \\
0.1198 & $\mathrm{lb} / \mathrm{gal}$ & $\mathrm{kg} \cdot \mathrm{L}^{-1}$ & 8.3454 \\
1 & $\mathrm{ppm}$ & $\mathrm{mg} \cdot \mathrm{L}^{-1}$ & 1 \\
6.8948 & $\mathrm{psi}$ & $\mathrm{kPa}$ & 0.1450
\end{tabular}


can reduce drift (Mortensen et al., 2012). In addition, modern formulations of 2,4-D and dicamba are less volatile than previous formulations (Havens et al., 2018; Sosnoskie et al., 2015). However, if applicators fail to use appropriate application practices out of convenience or cost, the risks of off-target movement increase. The availability of new synthetic auxinresistant herbicides will enable growers to apply these materials later into the growing season when susceptible crops and nontarget vegetation are mature, further increasing the potential for nontarget drift damage.

Heterogeneous landscapes provide specific challenges to the issue of herbicide drift. A large number of agronomic and horticultural crops are susceptible to injury and yield loss from drift-level exposures to synthetic auxin herbicides (Al-Khatib and Peterson, 1999; Breeze and West, 1987; Everitt and Keeling, 2009). Georgia ranks first in U.S. pecan production, with an economic value of more than \$401 million (Wolfe and Stubbs, 2018). Cotton, field corn, and soybean account for more than $\$ 1.2$ billion in farm gate value for the state (Wolfe and Stubbs 2018). Pecan orchards in the region are often found growing adjacent to fields of annual row-crops. This has historically made herbicide drift onto pecan trees from adjacent row crop fields a common occurrence when herbicide applications were made under the wrong conditions.

Prior research with 2,4-D and dicamba in 80-year-old pecan orchards indicated that $2,4-\mathrm{D}$ is less injurious than dicamba and that pecan trees can safely tolerate exposure to both herbicides if applied during the dormant season (Wood and Reilly, 2004). The objective of this study was to determine the potential effects of simulated, single drift events of 2,4-D and dicamba on pecan trees when applied during late May to early June. This period was selected because row crop producers make applications of 2,4-D and dicamba to herbicideresistant cotton and soybeans at that time and this is when most herbicide drift with these materials would occur.

\section{Materials and methods}

The study was conducted from 2013 to 2017 at the University of Georgia Ponder Research Farm near

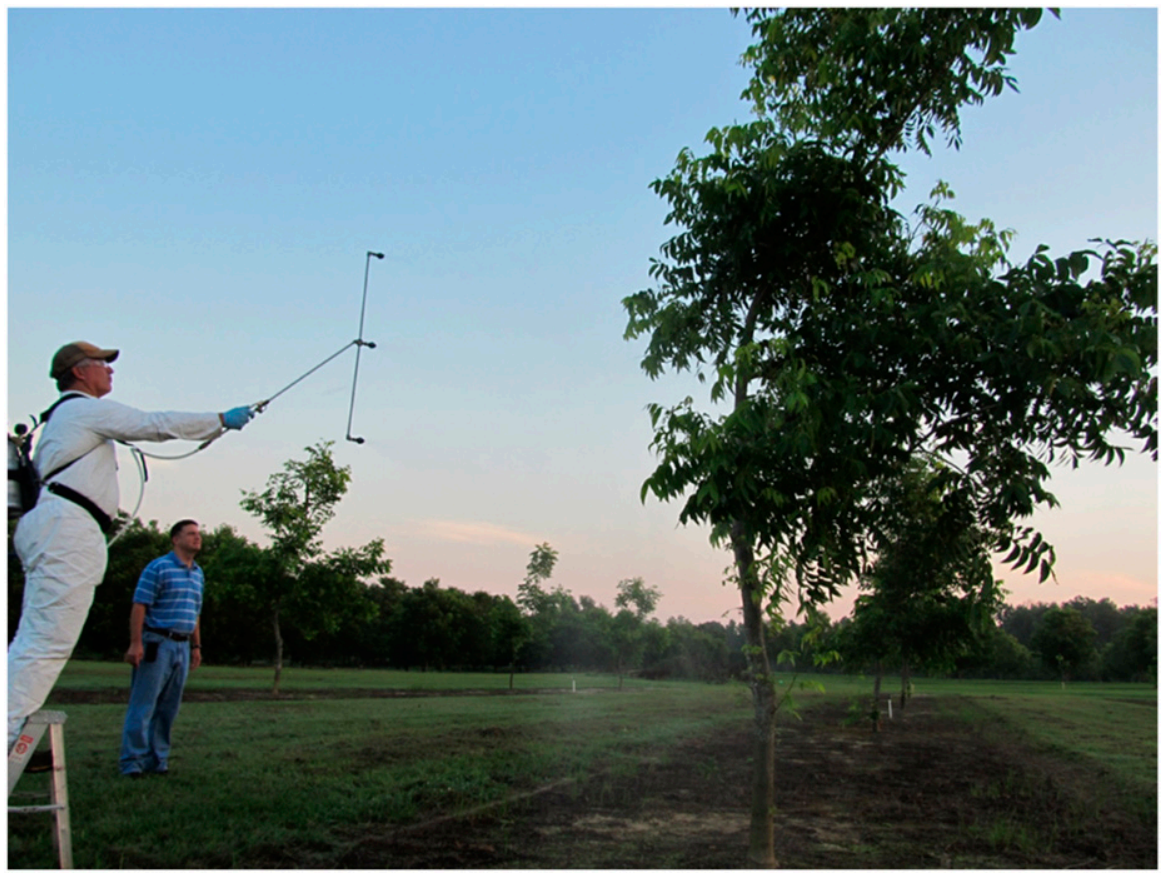

Fig. 1. Simulated herbicide drift application into pecan tree canopy in June 2013.

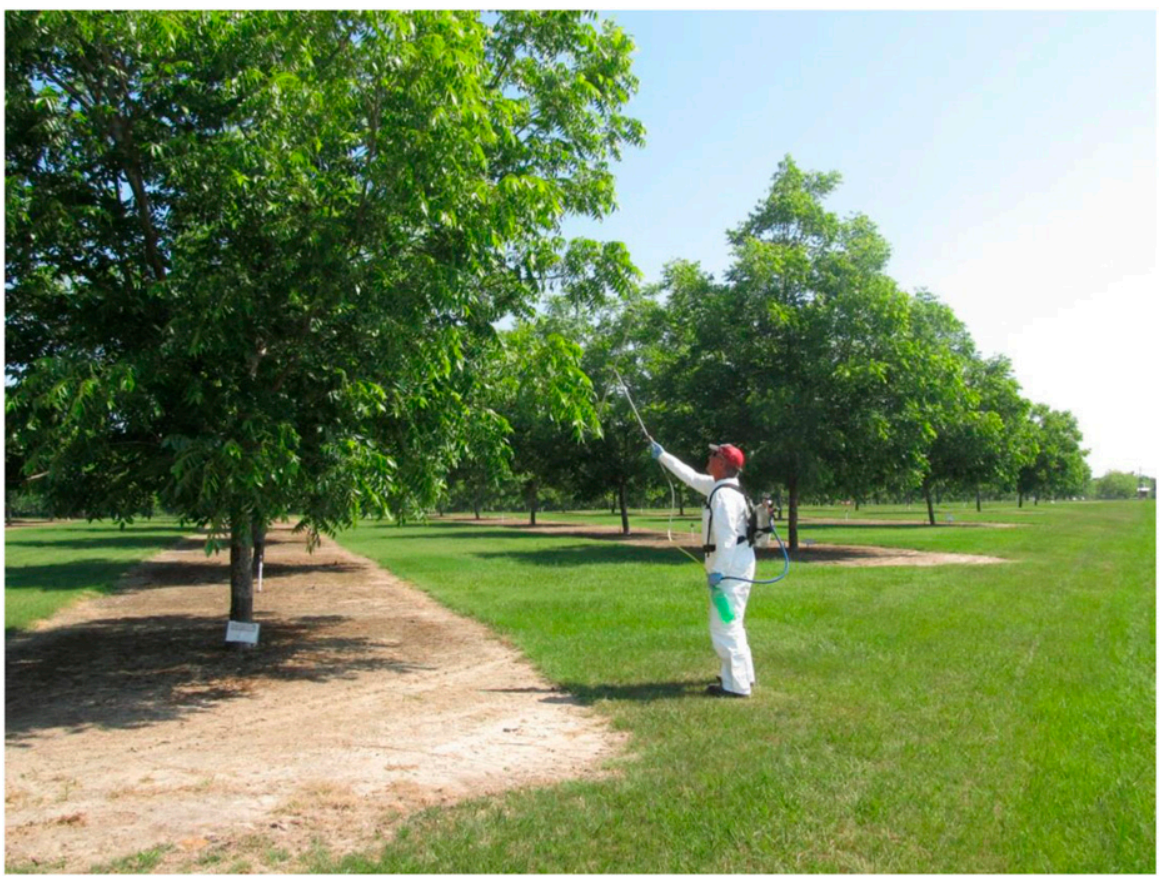

Fig. 2. Simulated herbicide drift application into pecan tree canopy in May 2016.

Tifton, GA. The orchard was located at lat. $31^{\circ} 50^{\prime} \mathrm{N}$ and long. $83^{\circ} 65^{\prime} \mathrm{W}$. 'Desirable' pecan trees were planted in Jan. 2008 at a spacing of $40 \times 40 \mathrm{ft}$. 'Desirable' is one of the most common cultivars grown in Georgia. All trees were irrigated by solid-set irrigation sprinklers. The orchard was managed under commercial conditions according to University of Georgia Cooperative Extension recommendations (Hudson et al., 2012). A 12 -ft-wide vegetationfree strip was maintained with the herbicide glyphosate along the tree row in all plots. Row middles consisted of bermudagrass (Cynodon dactylon) sod.

2013-14 EXPERIMENTS. In June 2013, 2,4-D amine $(3.8 \mathrm{lb} / \mathrm{gal}$ acid equivalent) or dicamba-Diglycolamine salt $[\mathrm{DGA}(4.0 \mathrm{lb} /$ gal a.e. $)]$ were applied in $1.0 \%, 0.1 \%$, and $0.01 \%$ by volume spray solutions to pecan trees that were 
15 to $20 \mathrm{ft}$ tall and at the beginning of nut-sizing stage of growth. These formulations of 2,4-D and dicamba were used in the 2013-14 experiments because the authors did not have access to the 2,4-D choline and dicambaN,N-Bis-(3-aminopropyl) methylamine (BAPMA) formulations used later in 2016-17. Normal use rates of these dicamba and 2,4-D formulations in auxin-tolerant crops applied in $15 \mathrm{gal} /$ acre would be equivalent to $0.83 \%$ by volume and $1.25 \%$ to $1.67 \%$ by volume, respectively. Treatments were applied into the pecan canopy using a vertical, hand-held, three-nozzle spray boom [carbon dioxide $\left(\mathrm{CO}_{2}\right)$-pressurized, 20 -inch nozzle spacing, 8002 nozzle tips (TeeJet Technologies, Springfield, IL), 40 psi]. Herbicide applications were made by standing on a 3 -ft stepladder placed $10 \mathrm{ft}$ from each tree. The various $2,4-\mathrm{D}$ and dicamba solutions were then sprayed into each tree for a duration of $10 \mathrm{~s}$ (Fig. 1). Approximately $400 \mathrm{~mL}$ of herbicide solution was applied per tree. Each herbicide treatment was replicated on three trees. Herbicide applications were not made to the same individual trees for more than 1 year.

Visual estimates of herbicide injury severity were made in July 2013, Oct. 2013, and July 2014. Oct. 2017 severity estimates were made to assess for further injury symptoms before natural defoliation. Visual estimates of herbicide injury severity were obtained using a rating scale from 0 to 10 with $0=$ no damage, $1-3=$ minor foliar damage symptoms $(10 \%$ to $30 \%$ of foliage with visible symptoms), $4-6=$ severe foliar damage symptoms $(>30 \%$ to $60 \%$ of foliage with visible symptoms and/or weak/ stunted/branches/limbs), and 7-10 = (>60\% to $100 \%$ foliage with visible symptoms and/or dead limbs/ branches). All severity ratings were made on the side of the tree to which herbicide applications were made.

2016-17 EXPERIMENTS. In May $2016,2,4-\mathrm{D}$ choline $(3.8 \mathrm{lb} /$ gal a.e. $)$ or dicamba-BAPMA $(5.0 \mathrm{lb} / \mathrm{gal}$ a.e. $)$ were applied in $1.0 \%, 0.1 \%$, and $0.01 \%$ by volume spray solutions to pecan trees that were 20 to $25 \mathrm{ft}$ tall. Normal use rates of dicamba and 2,4-D in auxintolerant crops applied in $15 \mathrm{gal} / \mathrm{acre}$ would be equivalent to $0.65 \%$ by volume and $1.25 \%$ by volume, respectively. Treatments were applied into the pecan canopy using a vertical, hand-held, three-nozzle spray boom $\left[\mathrm{CO}_{2}-\right.$ pressurized, 20-inch nozzle spacing, 11002DG nozzle tips (TeeJet Technologies), 40 psi]. Herbicide applications were made by spraying $\approx 400 \mathrm{~mL}$ of the herbicide solution into the tree canopy while walking around one-half perimeter of the tree (Fig. 2). Each herbicide treatment was replicated on three trees.

In May 2017, 2,4-D choline (3.8 $\mathrm{lb} /$ gal a.e.) or dicamba-BAPMA $(5.0$ $\mathrm{lb} / \mathrm{gal}$ a.e.) were applied in $1.0 \%, 0.1 \%$, and $0.01 \%$ by volume spray solutions to pecan trees that were 20 to $25 \mathrm{ft}$ tall. Treatments were applied into the pecan canopy using a vertical, hand-held, three-nozzle spray boom $\left(\mathrm{CO}_{2}-\right.$ pressurized, 20-inch nozzle spacing,

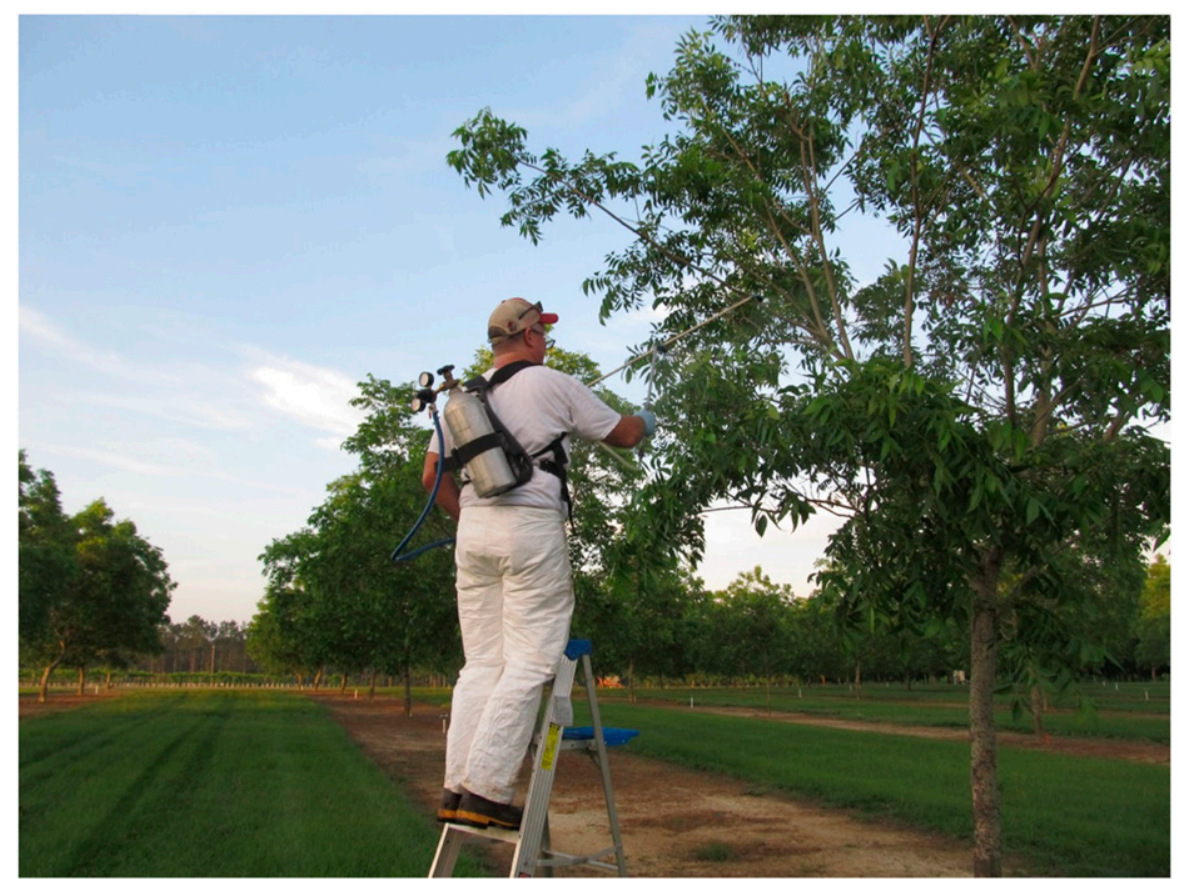

Fig. 3. Simulated herbicide drift application into pecan tree canopy in May 2017.

Table 1. Severity of herbicide injury from 2,4-D and dicamba on pecan in July and Oct. 2013 following treatment in June 2013.

\begin{tabular}{lccc}
\hline Herbicide & $\begin{array}{c}\text { Application rate } \\
\text { (\% by vol) }\end{array}$ & $\begin{array}{c}\text { July 2013 Herbicide } \\
\text { injury severity } \\
(\mathbf{0}-10 \text { scale })^{\mathrm{z}}\end{array}$ & $\begin{array}{c}\text { Oct. 2013 Herbicide } \\
\text { injury severity (0-10 scale) }\end{array}$ \\
\hline Dicamba & 1.0 & $5.8 \mathrm{bb}^{\mathrm{y}}$ & $10.0 \mathrm{a}$ \\
& 0.1 & $4.0 \mathrm{~b}$ & $4.3 \mathrm{~b}$ \\
& 0.01 & $0.3 \mathrm{c}$ & $5.3 \mathrm{~b}$ \\
$2,4-\mathrm{D}$ & 1.0 & $6.7 \mathrm{a}$ & $9.3 \mathrm{a}$ \\
& 0.1 & $3.7 \mathrm{~b}$ & $5.3 \mathrm{~b}$ \\
Control & 0.01 & $1.3 \mathrm{c}$ & $0.0 \mathrm{c}$ \\
& - & $0.0 \mathrm{c}$ & $0.0 \mathrm{c}$
\end{tabular}

${ }^{\mathrm{z}}$ Visual estimates of herbicide injury severity were obtained using a rating scale from 0 to 10 with $0=$ no damage, $1-$ $3=$ minor foliar damage symptoms ( $10 \%$ to $30 \%$ of foliage with visible symptoms), $4-6=$ severe foliar damage symptoms ( $>30 \%$ to $60 \%$ of foliage with visible symptoms and/or weak/stunted/branches $/$ limbs), and $7-10=$ (>60\% to $100 \%$ foliage with visible symptoms and/or dead limbs/branches).

${ }^{y}$ Means in the same column with the same letter are not significantly different within year according to Duncan's multiple range test $(P \leq 0.10)$. 
(SPAD-502; Minolta, Ramsey, NJ). All leaves measured for leaf area and LCI were fully expanded and selected from one pair of middle leaflets of compound leaves.

Leaf tissue concentration of 2,4$\mathrm{D}$ and dicamba in pecan foliage was tested in 2017. Thirty pairs of leaflets from each tree, including control trees, were collected on I June 2017 from the side of the tree to which herbicides were applied. Herbicide concentration of leaflets was analyzed by a gas chromatography mass spectrometer. Analysis was conducted by a private laboratory (Water Agricultural Laboratories, Camilla, GA).

Pecan yield was estimated in 2016 and 2017 by shaking trees and measuring the weight of nuts in a wedge-shaped grid consisting of $1 / 100$ of the area beneath the tree (Worley and Smith, 1984). Four subsample grids were used per tree, the weight summed, and multiplied by 25 to obtain the total tree yield. Only nongerminated, marketable nuts were used to measure yield. A 50-nut sample was collected from each tree for analysis of individual nut weight and percent kernel. Nuts were shelled and percentage of edible kernel was calculated by dividing the kernel weight for the 50 -nut sample by total nut weight. Pecan yield data were not collected in 2018 due to Hurricane Michael.

All data were subjected to analysis of variance with means separated using Duncan's multiple range test when appropriate $(P \leq 0.10)$.

\section{Results and discussion}

Trees receiving simulated single drift events of dicamba and 2,4-D at each of the three rates evaluated exhibited visible symptoms of injury at each sampling date in 2013 and 2014 , with the exception of the lowest rate of 2,4-D in the Oct. 2013 rating (Tables 1 and 2). Minor symptoms of injury appeared as deformed leaves, often exhibiting cupping or leaf curling (Fig. 4). The severity of symptoms of trees progressed with chemical contact at higher herbicide rates resulting in die-back of foliage (Fig. 5) and major limb death (Fig. 6). Such limbs were on the side of the tree to which applications were made and were in the path of the herbicide as it was sprayed. The $0.01 \%$ treatment of dicamba and 2,4-D and the control had lower severity ratings of herbicide injury than each of the other herbicide treatments in July 2013 (Table 1). Herbicide severity ratings were higher for $1.0 \% 2,4-\mathrm{D}$ in July 2013 than in all other treatments, with the exception of $1.0 \%$ dicamba (Table 1 ). The $0.1 \%$ dicamba and $0.1 \%$ 2,4-D treatments had higher severity ratings than the $0.01 \%$ herbicide treatments and control in July 2013 (Table 1 ).

In Oct. 2013, the $1.0 \%$ rates of both herbicides had higher severity ratings than all other treatments. These treatments resulted in the death of individual branches in contact with the herbicides at this rate. Severity ratings for $0.1 \%$ dicamba, $0.01 \%$ dicamba, and $0.1 \% 2,4-\mathrm{D}$ were higher than both the $0.01 \% 2,4-\mathrm{D}$ and control treatments in Oct. 2013 (Table 1).

In July 2014, some herbicide injury was still evident in all treatments.
Generally, there was no difference in pecan response to dicamba or 2,4-D. The $1.0 \%$ rate of both dicamba and 2,4-D caused the greatest herbicide injury severity. No differences in severity were observed between the $0.1 \%$ and $0.01 \%$ rates of either herbicide (Table 2).

During 2016 and 2017, herbicide severity was rated by estimation of total percent damage observed on individual trees. Percent damage was greater at the $1.0 \%$ volume concentrations of both herbicides as compared with lower rates in 2016 (Table 3 ). In 2017, percent damage was greater for $2,4-\mathrm{D}$ at the $1.0 \%$ rate than at all other rates (Table 3 ). However, no negative effects were observed on pecan yield (Table 4). Some differences in kernel percentage were observed but were not consistent (Table 4). Concentrations of herbicide in tree foliage were highest in these treatments as well (Table 5).

Table 2. Severity rating of herbicide injury from 2,4-D and dicamba on pecan in July 2014 following treatment in June 2013.

\begin{tabular}{lcc}
\hline Herbicide & Application rate (\% by vol) & Herbicide injury severity (0-10 scale $)^{\mathrm{z}}$ \\
\hline Dicamba & 1.0 & $8.0 \mathrm{a}^{\mathrm{y}}$ \\
& 0.1 & $5.0 \mathrm{~b}$ \\
$2,4-\mathrm{D}$ & 0.01 & $3.3 \mathrm{bc}$ \\
& 1.0 & $8.3 \mathrm{a}$ \\
& 0.1 & $5.3 \mathrm{~b}$ \\
Control & 0.01 & $5.7 \mathrm{~b}$ \\
\hline
\end{tabular}

${ }^{\mathrm{z}}$ Visual estimates of herbicide injury severity were obtained using a rating scale from 0 to 10 with $0=$ no damage, $1-$ $3=$ minor foliar damage symptoms ( $10 \%$ to $30 \%$ of foliage with visible symptoms), 4-6 = severe foliar damage symptoms $(>30 \%$ to $60 \%$ of foliage with visible symptoms and/or weak/stunted/branches $/$ limbs), and $7-10=$ ( $>60 \%$ to $100 \%$ foliage with visible symptoms and/or dead limbs/branches).

${ }^{y}$ Means in the same column with the same letter are not significantly different according to Duncan's multiple range test $(P \leq 0.10)$

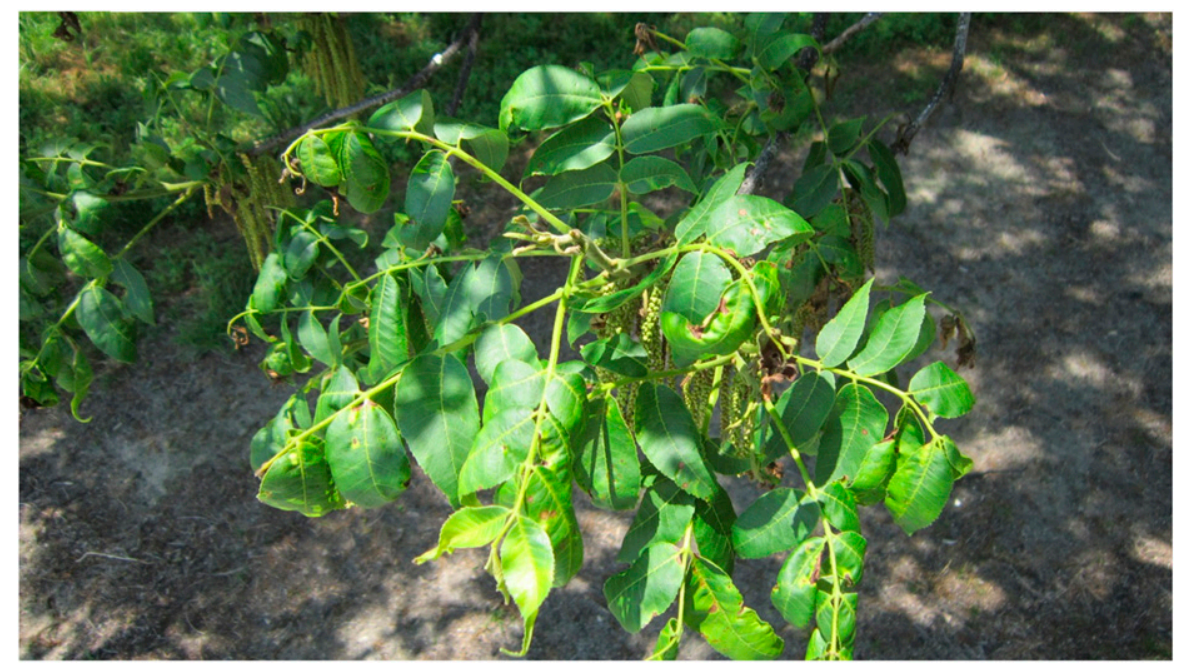

Fig. 4. Foliar injury of pecan trees treated with 2,4-D herbicide. These initial symptoms of injury were observed at each level of treatment during the course of the study. 


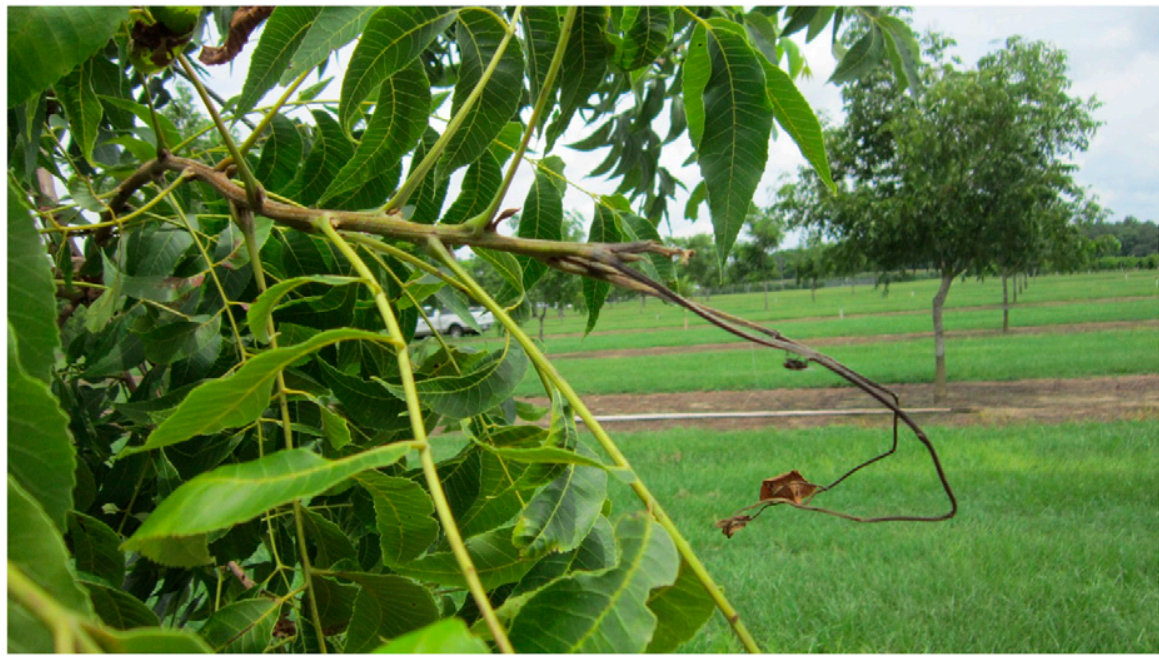

Fig. 5. Foliar injury of pecan trees treated with dicamba herbicide. These symptoms were rated as $4-6$ on the severity scale ( $>30 \%$ to $60 \%$ of foliage with visible symptoms and/or weak/stunted/branches/limbs).

An additional symptom of herbicide injury was observed in 2017 in the form of arrested nut development. Nuts on some of the live branches adjacent to dead branches remained alive but failed to increase normally in size and maturity beyond the state they were in at the time of application (Fig. 5). It is not known whether this was a result of drift whereby damaged tissues had less contact with the material or a result of possible translocation.

These results suggest that serious injury can occur to pecan trees receiving herbicide contact at rates of $1.0 \%$ by volume dicamba or $2,4-\mathrm{D}$. This injury includes deformed foliage (Fig. 4), dead foliage (Fig. 5), dead limbs and/or branches (Fig. 6), and arrested nut development (Fig. 7). Mohseni-Moghadam et al. (2016) observed injury symptoms greater than $10 \% \quad 42$ d after treatment (DAT) in wine grapes (Vitis vinifera) treated with 2,4-D at all rates examined and with dicamba at the highest rates. Injury levels of 35\% were observed at 357 DAT only in plants treated with the highest rate of 2,4D (Mohseni-Moghadam et al., 2016). Dicamba and 2,4-D are translocated by symplastic and apoplastic pathways and accumulate at the growing points of plants (Shaner, 2014). It is possible that a higher concentration of either of these herbicides would lead to increased translocation and higher levels of injury on foliage. It is also unclear at this time whether the observed arrested nut development resulted from translocation or more direct contact.

Tissue concentrations of herbicide in leaves measured 33.5 and 26.9 ppm for dicamba and 2,4-D, respectively at the highest rate used (Table $5)$. At the $0.1 \%$ by volume rate, only 1.7 and $3.3 \mathrm{ppm}$ were observed for dicamba and 2,4-D, respectively. No herbicide was detected in leaf tissue receiving the $0.01 \%$ by volume rate of either material or the control (Table 5 ). Rates $<1.0 \%$ by volume may result in less severe injury; however, cosmetic injury would still be apparent. Previously, applications of 2,4-D $(0.52 \%$ to $2.25 \%$ by volume $)$ or dicamba $(0.6 \%$ to $2.4 \%$ by volume $)$ for mistletoe (Viscum album) control in pecan trees led to delayed budbreak, leaf deformity, and reduced leaf size when trees were treated within 3 weeks before bud-break (Wood and Reilly, 2004). In addition, 2,4-D application resulted in death of pecan limbs $<1$ inch in diameter but caused no long-term adverse effects to large ( $>40 \mathrm{ft}$ height) pecan trees (Wood and Reilly, 2004).

Dead branches resulting from contact with $1.0 \%$ by volume solutions of 2,4-D and dicamba in 2013 were removed during the winter following application. Observations of trees up to 5 years following initial application suggest the trees recovered from the herbicide application in that none have shown visible symptoms of injury beyond the dead limbs observed on trees to which the $1.0 \%$ by volume concentration was applied

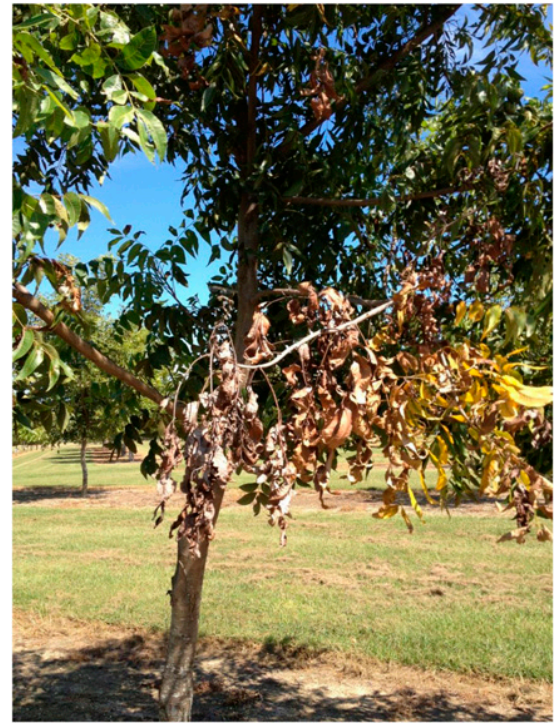

Fig. 6. Dead pecan limbs resulting from $1.0 \%$ by volume application of synthetic auxin herbicide. These symptoms were rated as $7-10$ on the severity scale ( $>60 \%$ to $100 \%$ foliage with visible symptoms and/or dead limbs/branches).

nor was their yield impacted compared with the control. Percent kernel was reduced in all 2,4-D treatments and in the $1.0 \%$ by volume dicamba treatment in 2017, 4 years following application (Table 4). This was the only year in which percent kernel was affected. In addition, the death of individual branches in the path of the spray of either 2,4-D or dicamba at $1.0 \%$ by volume or greater suggests that the woody tissue of pecan trees and potentially entire trees in contact with high concentrations of these materials are susceptible to serious injury and/or death. Injury from herbicide drift onto off-target crops is highly variable, depending on many factors, such as wind speed, temperature, boom height, ground speed of equipment, herbicide formulation, herbicide rate, and concentration of the herbicide material making contact with off-target tissue. As a result, herbicide drift is difficult to simulate in an experimental setting.

In summary, the following conclusions are noteworthy: 1) There were no major differences in the response of pecan to either dicamba or 2,4-D at similar rates in this study; 2) pecan damage resulting from off-target movement of 2,4-D and dicamba at rates $\geq 1 \%$ by volume have the potential to cause significant injury; and 3 ) yield was not negatively affected by any of 
Table 3. Percent damage from 2,4-D and dicamba and leaf chlorophyll index of pecan in July 2016 and Aug. 2017 following treatment in May 2016 and 2017.

\begin{tabular}{|c|c|c|c|c|}
\hline Yr of application & Herbicide & Application rate (\% by vol) & Herbicide injury (\% damage $)^{\mathrm{z}}$ & Chlorophyll index (SPAD) $)^{y}$ \\
\hline \multicolumn{5}{|l|}{2016} \\
\hline & Dicamba & 1.0 & $21.7 b^{x}$ & $34 \mathrm{a}$ \\
\hline & & 0.1 & $0.3 \mathrm{~d}$ & $44 \mathrm{a}$ \\
\hline & & 0.01 & $0.0 \mathrm{~d}$ & $40 \mathrm{a}$ \\
\hline & 2,4-D & 1.0 & $30.0 \mathrm{a}$ & $29 a$ \\
\hline & & 0.1 & $0.3 \mathrm{~d}$ & $39 a$ \\
\hline \multicolumn{5}{|l|}{2017} \\
\hline & Dicamba & 1.0 & $10 \mathrm{ab}$ & $35 \mathrm{~b}$ \\
\hline & & 0.1 & $\mathrm{lb}$ & $45 \mathrm{a}$ \\
\hline & & 0.01 & $0 \mathrm{~b}$ & $39 \mathrm{ab}$ \\
\hline & 2,4-D & 1.0 & $25 \mathrm{a}$ & $29 \mathrm{c}$ \\
\hline & & 0.1 & $3.5 \mathrm{~b}$ & $38 \mathrm{ab}$ \\
\hline
\end{tabular}

${ }^{\mathrm{z}}$ Percentage of the tree canopy showing visual damage symptoms.

${ }^{y}$ Chlorophyll meter (SPAD-502; Minolta, Ramsey, NJ).

${ }^{\mathrm{x}}$ Means in the same column with the same letter are not significantly different within year according to Duncan's multiple range test $(P \leq 0.10)$.

Table 4. Mean pecan yields and percent kernel observed from 2,4-D and dicamba application during the year of application and in subsequent years.

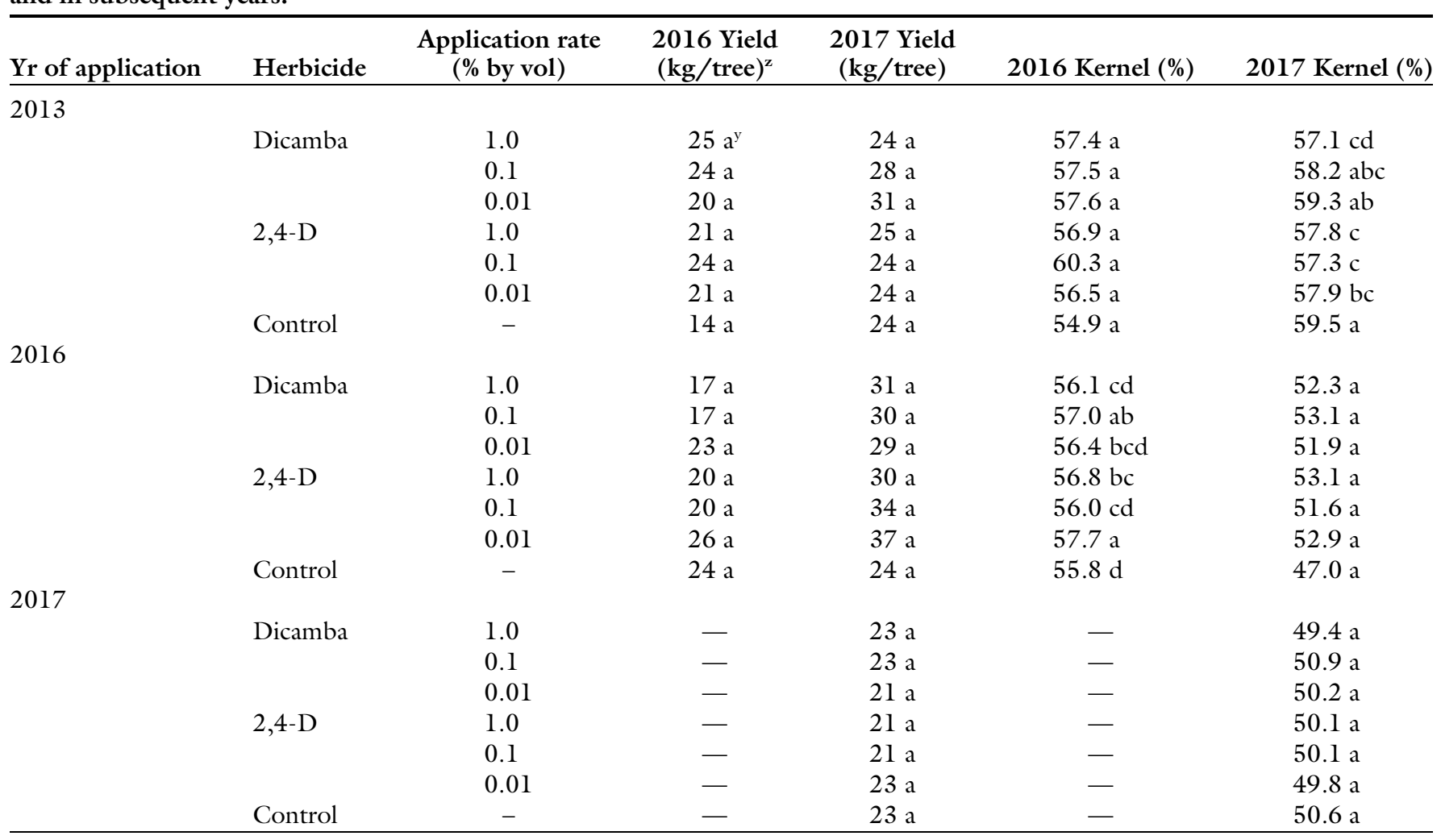

\footnotetext{
${ }^{\mathrm{z}} 1 \mathrm{~kg}=2.2046 \mathrm{lb}$.
}

${ }^{\mathrm{y}}$ Means in the same column with the same letter are not significantly different within year according to Duncan's multiple range test $(P \leq 0.10)$.

the treatments in the current study, suggesting that pecan trees can compensate for the observed injury to still produce in a similar manner to untreated trees. The effect of treatments on percent kernel was variable. Percent kernel of pecans from trees treated in 2013 with the $1 \%$ rate of dicamba and all rates of 2,4-D was lower than that of the control in 2017 (Table 4). The reduction from $59.5 \%$ to $57.1 \%$ can be economically significant for growers. For trees treated in 2016, the $0.1 \%$ dicamba and $1.0 \%$ and $0.01 \% 2,4-\mathrm{D}$ treatments had higher percent kernel than that of the control in the same year
(Table 4). High rates of dicamba resulted in abnormally small-sized nuts and reduced development on limbs receiving contact with the herbicide (Fig. 7).

Normal use rates of dicambaBAPMA and 2,4-D choline in auxin tolerant crops applied in $15 \mathrm{gal} / \mathrm{acre}$ 
Table 5. Pecan leaf tissue concentrations of 2,4-D and dicamba following treatment at $0 \%, 0.01 \%, 0.1 \%$, and $1.0 \%$ by volume.

\begin{tabular}{lcc}
\hline Herbicide & Application rate $(\% \text { by vol })^{\mathrm{z}}$ & Leaf tissue concn $(\mathbf{p p m})^{\mathrm{y}}$ \\
\hline Dicamba & 1.0 & $33.5 \mathrm{a}^{\mathrm{x}}$ \\
& 0.1 & $1.7 \mathrm{bc}$ \\
$2,4-\mathrm{D}$ & 0.01 & $0.0 \mathrm{c}$ \\
& 1.0 & $26.9 \mathrm{a}$ \\
& 0.1 & $3.3 \mathrm{~b}$ \\
Control & 0.01 & $0.0 \mathrm{c}$ \\
\end{tabular}

${ }^{\mathrm{z}}$ Treatments applied 18 May 2017

${ }^{\mathrm{y}}$ Leaf samples collected 1 June $2017 ; 1 \mathrm{ppm}=1 \mathrm{mg} \cdot \mathrm{L}^{-1}$

${ }^{\mathrm{x}}$ Means in the same column with the same letter are not significantly different according to Duncan's multiple range test $(P \leq 0.10)$.

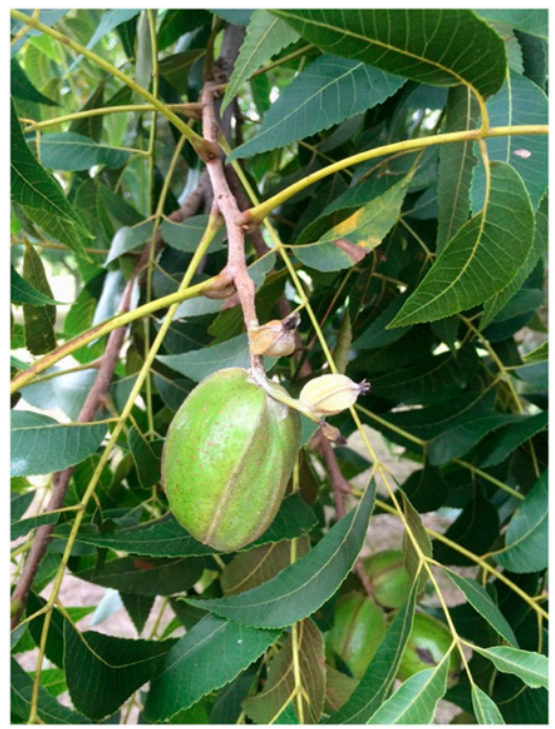

Fig. 7. Arrested nut development observed on pecan trees treated with dicamba.

would be equivalent to $0.83 \%$ by volume and $1.25 \%$ to $1.67 \%$ by volume, respectively. Volatility and physical drift rates are typically lower than normal application rates with the exception of plants in close proximity to the site of application. Thus, it is possible that minor drift rates of 2,4-D or dicamba will not cause long-term effects on pecan trees when used according to labeled directions.

Drift hazards and the effects of auxin herbicide spray drift on woody perennials and fruit trees have been commonly observed and well documented since their discovery in the 1940s (Bondada, 2011). The current study suggests that the effect of auxin herbicide spray drift on pecan trees may be highly variable, depending largely on coverage and herbicide concentration. The manufacturers of 2,4-D and dicamba-resistant crop technologies have developed rigorous safety guidelines and label use requirements to prevent off-target movement and damage from herbicide drift. In addition, university and industry personnel have developed robust training programs to address off-target movement of pesticides. However, producers using this technology must follow these requirements to ensure prevention of off-target movement.

\section{Literature cited}

Al-Khatib, K. and D. Peterson. 1999. Soybean response to simulated drift from selected sulfonylurea herbicides, dicamba, glyphosate, and glufosinate. Weed Technol. 13:264-270.

Behrens, M.R., N. Mutlu, S. Charkrborty, R. Dumitru, W.Z. Jiang, B.J. LaVallee, P.L. Herman, T.E. Clements, and D.P. Weeks. 2007. Dicamba resistance: Enlarging and preserving biotechnology-based weed management strategies. Science 316:1185-1188.

Behrens, R. and W.E. Lueschen. 1979. Dicamba volatility. Weed Sci. 27:486-493.

Breeze, V.G. and C.J. West. 1987. Effects of 2,4-D butyl vapor on the growth of six crop species. Ann. Appl. Biol. 111:185-191.

Bondada, B.R. 2011. Anomalies in structure, growth characteristics, and nutritional composition as induced by 2,4-dichlorophenoxy acetic acid drift phytotoxicity in grapevine leaves and clusters. J. Amer. Soc. Hort. Sci. 136:165-176.

Duke, S.O. and S.B. Powles. 2009. Glyphosate resistant crops and weeds: Now and in the future. AgBioForum 12:346-357.

Everitt, J.D. and J.W. Keeling. 2009. Cotton growth and yield response to simulated 2,4-D and dicamba drift. Weed Technol. 23:503-506.

Grover, R., J. Maybank, and K. Yoshida. 1972. Droplet and vapor drift from butyl ester and dimathethylamine salt of 2,4-D. Weed Sci. 20:320-324.
Havens, P.L., D.E. Hilger, A.J. Hewitt, G.R. Kruger, L. Marchi-Werle, and Z. Czaczyk. 2018. Field measurements of drift of conventional and drift control formulations of 2,4-D Plus glyphosate. Weed Technol. 32:550-556.

Heap, I. 2018. The International Survey of Herbicide Resistant Weeds. 26 Nov. 2018. <http://www.weedscience.org>.

Hudson, W., J. Brock, S. Culpepper, and L. Wells. 2012. Georgia pecan pest management guide. Univ. Georgia Coop. Ext. Bul. 841.

Mohseni-Moghadam, M., S. Wolfe, I. Dami, and D. Doohan. 2016. Response of wine grape cultivars to simulated drift rates of 2,4-D, dicamba, and glyphosate. Weed Technol. 30:807-814.

Monaco, T.J., S.C. Weller, and F.M. Ashton. 2002. Weed science: Principles and practices. Wiley, New York, NY.

Mortensen, D.A., J.F. Egan, B.D. Maxwell, M.R. Ryan, and R.G. Smith. 2012. Navigating a critical juncture of sustainable weed management. Bioscience 62:75-84.

Sciumbato, A.S., J.M. Chandler, S.A. Senseman, R.W. Bovey, and K.L. Smith. 2004. Determining exposure to auxinlike herbicides. I. Quantifying injury to cotton and soybean. Weed Technol. 18:1125-1134.

Sosnoskie, L.M., A.S. Culpepper, L.B. Braxton, and J.S. Riuchburg. 2015. Evaluating the volatility of three formulations of 2,4-D when applied in the field. Weed Technol. 29:177-184.

Shaner, D.L. 2014. Herbicide handbook. Weed Sci. Soc. Amer., Lawrence, KS.

U.S. Department of Agriculture. 2018. Cotton varieties planted 2018 crop. U.S. Dept. Agr., Agr. Mktg. Serv., Cotton Tobacco Program mp_cn833.

Wood, B.W. and C.C. Reilly. 2004. Control of mistletoe in pecan trees. HortScience 39:110-114.

Wolfe, K. and K. Stubbs. 2018. Georgia farm gate value report. Univ. Georgia Coop. Ext. AR-18-01.

Worley, R.E. and M. Smith. 1984. A method of estimating pecan yield. HortScience 19:664.

Wright, T.R., G. Shan, T.A. Walsh, J.M. Lira, C. Cui, P. Song, M. Zhuang, N.L. Arnold, G. Lin, K. Yau, S.M. Russell, R.M. Cicchillo, M.A. Peterson, D.M. Simpson, N. Zhou, J. Ponsamuel, and Z. Zhang. 2010. Robust crop resistance to broadleaf and grass herbicides provided by arloxyalkanoate dioxygenase transgenes. Proc. Natl. Acad. Sci. USA 107:20240-20245. 